\title{
KOMUNIKASI DAN HUMAN RELATION PENDIDIKAN BERBASIS AGAMA FILSAFAT, PSIKOLOGI DAN SOSIOLOGI
}

\author{
Fahrizal Akhirudin ${ }^{1}$, Ujang Nurjaman ${ }^{2}$ \\ ${ }^{1}$ Sekolah Pascasarjana Universitas Islam Nusantara, Bandung, Indonesia \\ fahrizalakhirudin@gmail.com \\ ${ }^{2}$ Sekolah Pascasarjana Universitas Islam Nusantara, Bandung, Indonesia \\ Ujangnurjaman@gmail.com
}

\begin{abstract}
Abstrak
Salah satu permasalahan yang kerap muncul di dalam organisasi adalah ketidakharmonisan hubungan antara pimpinan dengan anggotanya, atau antara sesama anggota. Permasalahan ini disebabkan adanya hambatan gangguan dalam komunikasi organisasi. Tujuan dari makalah adalah untuk mengetahi dan mengkaji: 1) Bagaiaman komunikasi dan human relation pendidikan berbasis agama. 2) Bagaimana komunikasi dan human relation pendidikan berbasis filsafat 3) Bagaimana komunikasi dan human relation pendidikan berbasis psikologis. 4) Bagaimana komunikasi dan human relation pendidikan berbasis sosiologi dan 5) Ide kreatif apa yang dibutuhkan dalam membangun komunikasi dan Human relation pendidikan. Hasil kajian ini adalah Islam mengajarkan umatnya untuk senantiasa menjaga hubungannya dengan manusia (hablum min as-naas), di samping menjaga hubungannya dengan AllahSWT (hablum min Allah). Paradigma positivisme mendefiniskan komunikasi sebagi suatu proses sebab-akibat, yang mencerminkan pengirim pesan (komunikator/encoder) untuk mengubah pengetahuan (sikap atau perilaku) penerima pesan (komunikan/decoder) yang pasif. Dalam membina human relation, maka eksistensi masing-masing individu di dalam organisasi diakui dan dihormati. Manusia di dalam suatu organisasi baik hubungan formal maupun informal dalam menciptakan dan mewujudkan suatu kerja sama yang intim dan harmonis guna mencapai tujuan yang telah ditetapkan dengan di landasi saling pengertian dan saling menghargai. Kesimpulan makalah ini adalah urgensi human relation dalam komunikasi organisasi. Berdasarkan paparan-paparan dalam makalah ini dapat disimpulkan bahwa human relation merupakan salah satu teknik komunikasi yang harus diterapkan di dalam komunikasi organisasi guna mendukung pencapaian tujuan organisasi.

Kata Kunci: Komunikasi, human relation, agama, filsafat, psikologis dan sosiologis
\end{abstract}

\section{PENDAHULUAN}

Manusia adalah makhluk sosial untuk bertahan hidup manusia membutuhkan manusia lain hal ini tidak bisa dihindari. Komunikasi dan human relations merupakan hal yang sangat penting dalam kelancaran dan keberlangsungan suatu kegiatan apapun, terutama dalam suatu organisasi ataupun dalam hal pekerjaan. Karena suatu hubungan antara manusia yang baik akan menciptakan suatu keharmonisan untuk menyelesaikan suatu permasalahan. Manusia merupakan individu yang berbeda-beda maka secara langsung atau tidak langsung akan menciptakan permasalahan. Maka diperlukan diperlukan penguasaan komunikasi dan human relations yang baik untuk

Al Qalam: Jurnal Ilmiah Keagamaan dan Kemasyarakatan Vol. 16, No. 1

Januari - Juni 2022 
Fahrizal Akhirudin, Ujang Nurjaman : Momunikasi dan Human Relation Pendidikan Berbasis Agama, Filsafat, Psikologi dan Sosiologi

memecahkan suatu masalah yang ada.

Dalam penelitian Rizki, J. W. S. menyatakan bahwa salah satu permasalahan yang kerap muncul di dalam organisasi adalah ketidakharmonisan hubungan antara pimpinan dengan anggotanya, atau antara sesama anggota. Permasalahan ini disebabkan adanya hambatan gangguan dalam komunikasi organisasi. Seluruh aktivitas organisasi akan berjalan sesuai dengan tugas dan fungsinya masing-masing jika komunikasi berlangsung secara efektif dalam semua lini organisasi. Sebaliknya, kegagalan dalam membina komunikasi yang efektif dan harmonis, akan terhambatnya pelaksanaan tugas-tugas dalam organisasi. Tanpa komunikasi tidak ada koordinasi, dan tanpa koordinasi akan terjadi tumpang tindih pekerjaan, kesimpangsiuran informasi, dan kesalahpahaman dalam memaknai dan melaksanakan tugas-tugas keorganisasian. Pimpinan organisasi merupakan ujung tombak organisasi untuk mewujudkan kenyamanan, menghadirkan motivasi, serta menumbuhkan loyalitas terhadap organisasi. Oleh karena itu, seorang pimpinan organisasi harus memiliki kecerdasan dan kecakapan komunikasi melebihi kapasitas komunikasi anggotanya. ${ }^{1}$

Pelaksanaan komunikasi dan human relation di lembaga pendidikan memiliki kecenderungan belum terlaksana dengan baik. Terlihat adanya pegawai malas atau guru yang malas mengajar disebabkan suasana kerja kurang menyenangkan, terlambat menyelesaikan pekerjaan karena kurangnya perlengkapan memadai, kurangnya tanggung jawab bekerja karena tidak terlaksana prinsip the right man on the right place. Diduga prinsip human relation belum dilaksanakan cukup baik.

Komunikasi dan human relation merupakan inti dari kepemimpinan dan human relationmerupakan proses kegiatan yang dilakukan untuk memberikan pemuasan kebutuhan pegawai atau bawahan agar bekerja dengan baik dan agar para pegawai atau bawahan merasa senang sehingga mudah untuk digerakan demi tercapainya suatu tujuan organisasi. Agar tujuan dari organisasi dapat tercapai maka seorang pemimpin harus mengetahui bakat dan keahlian pegawainya serta harus memahami sifat hakiki dari setiap individu dalam organisassi dan memperkecil perbedaan antara orang-orang dalam organisasi yang merupakan prasyarat yang sangat penting dalam usaha menggerakan pegawainya. Penerapan human relation seorang pemimpin sangat diperlukan, karena human relations menjelaskan bagaimana menciptakan suatu hubungan yang harmonis diantara pegawai dengan pimpinan dalam suatu organisasi.

Salah satu upaya membentuk perilaku individu agar dapat bekerja sama dengan baik, serasi, harmonis, dan terarah disertai dengan perasaan bahagia serta tenang hati di antara kedua belah

1 Juni Wati Sri Rizki, "Urgensi Human Relation Bagi Organisasi," Studi Multidisipliner: Jurnal Kajian Keislaman 2, no. 1 (2015): h. 131.

Al Qalam: Jurnal Ilmiah Keagamaan dan Kemasyarakatan Vol. 16, No. 1

Januari - Juni 2022 
Fahrizal Akhirudin, Ujang Nurjaman : Momunikasi dan Human Relation Pendidikan Berbasis Agama, Filsafat, Psikologi dan Sosiologi

pihak, baik antara pimpinan maupun pegawai perlu di laksanakankomunikasi human relations. Dengan suasana kerja yang menyenangkan, para pegawai dapat mencurahkan tenanga serta pikirannya dengan penuh kesadaran dan rasa tanggung jawab yang tinggi terhadap pekerjaannya dalam rangka mencapai tujuan yang telah ditetapkan.

Komunikasi adalah sebuah tindakan untuk berbagi informasi, gagasan, ataupun pendapat dari setiap partisipan komunikasi yang terlibat di dalamnya guna mencapai kesamaan makna. Merujuk pada pemahaman tersebut, maka komunikasi merupakan aktivitas yang kompleks yang melibatkan pikiran, perasaan, ide-ide, dan kecakapan dalam mengemas dan menyampaikan informasi serta memaknainya Komunikasi adalah hal yang tidak mungkin dihindari dalam kehidupan, karena ia hadir dalam semua bidang, dalam berbagai konteks dan dalam berbagai lingkup (omnipresent), antara lain dalam lingkup organisasi. Komunikasi merupakan elemen penting dalam sebuah organisasi, baik formal maupun non formal. Seluruh aktivitas organisasi akan berjalan dengan baik sesuai dengan tugas dan fungsinya masing-masing jika komunikasi dalam organisasi berlangsung secara efektif dalam semua lini organisasi. Sebaliknya, kegagalan dalam membina komunikasi yang efektif dan harmonis akan menyebabkan terhambatnya pelaksanaan tugas-tugas dalam organisasi. Tanpa komunikasi tidak ada koordinasi, dan tanpa koordinasi akan terjadi tumpang tindih pekerjaan, kesimpangsiuran informasi, dan kesalahpahaman dalam memaknai dan melaksanakan tugas-tugas keorganisasian. ${ }^{2}$

Dalam konteks organisasi, pemahaman mengenai peristiwa-peristiwa komunikasi yang terjadi di dalamnya, lancar-tidaknya arus dan pola hubungan komunikasi antara pimpinan dan anggota serta efektif-tidaknya kinerja organisasi dalam rangka pencapaian tujuan bersama merupakan contoh sederhana untuk menggambarkan urgensi komunikasi di dalam organisasi. Pimpinan memegang peranan penting dalam membangun komunikasi yang efektif di dalam organisasi. Sebagai top leader, pimpinan organisasi seyogianya menjadi panutan sekaligus pengayom dalam organisasi. Pimpinan organisasi merupakan ujung tombak organisasi untuk mewujudkan kenyamanan dalam bekerja, menghadirkan motivasi untuk berprestasi, serta menumbuhkan loyalitas terhadap organisasi.

Human relations dalam arti luas adalah komunikasi persuasif yang akan dilakuakan oleh seorang kepada orang lain secara tatap muka dalam segala situasi dan dalam semua bidang kehidupan, sehingga menimbulkan kebahagiaan dan kepuasan hati pada kedua pihak. Jadi human relations dalam arti luas dilakukan di mana saja: di rumah, di jalan, di pasar, di toko dan sebagainya.

${ }^{2}$ Bungin Burhan, Sosiologi Komunikasi: Teori, Paradigma, Dan Diskursus Teknologi Komunikasi Di Masyarakat (Jakarta: Kencana Prenada Media Group, 2006), h. 267.

Al Qalam: Jurnal Ilmiah Keagamaan dan Kemasyarakatan Vol. 16, No. 1 Januari - Juni 2022 
Fahrizal Akhirudin, Ujang Nurjaman : Momunikasi dan Human Relation Pendidikan Berbasis Agama, Filsafat, Psikologi dan Sosiologi

Bagi seorang pemimpin (apapun jabatannya), human relations dalam segala situasi ini penting dilaksanakan, karena dalam segala situasi ini penting dilaksanakan, karena akan mencerminkan pribadinya dan citra organsasi yang dipimpinnya. Suksesnya seseorang dalam melaksanakan human relations, karena ia berkomunikasi secara etis: ramah, sopan, menghargai dan menghormati orang lain.

Dari uraian di atas dapat dirumuskan permasalahan dalam makalah ini, sebagai berikut: Bagaiaman komunikasi dan human relation pendidikan berbasis agama? Bagaimana komunikasi dan human relation pendidikan berbasis filsafat? Bagaimana komunikasi dan human relation pendidikan berbasis psikologis? Bagaimana komunikasi dan human relation pendidikan berbasis sosiologi? Ide kreatif apa yang dibutuhkan dalam membangun komunikasi dan Human relation pendidikan? Tujuan dari penulisan makalah ini adalah untuk mengetahui, menganalisis dan mendapatkan informasi komunikasi dan human relation pendidikan berbasis agama, filsafat, psikologi, dan sosiologi.

\section{METODE PENELITIAN}

Pelaksanaan penelitian diawali dengan pemilihan peneliti dengan menggunakan metode penelitian library research sebagai metode dan tekhnik pengumpulan data dengan mengumpulkan ragam literatur yang bisa dijadikan kajian teoritis. Data secara teoritis yang sudah dikumpulkan oleh peneliti selanjutnya dianalisis dengan tekhnik content analysis untuk "mengupas" data yang sudah dikumpulkan pada saat mengkaji ragam literatur yang sudah dikumpulkan pada tahap awal penelitian.

\section{HASIL DAN PEMBAHASAN}

\section{Komunikasi Dan Human Relation Pendidikan Berbasis Agama}

Kajian terhadap human relation hanya difokuskan pada suasana hubungan di lingkungan organisasi. Sedangkan dalam arti luas, human relation dapat berlangsung pada semua bidang kehidupan sosial, kapan saja, dandi mana saja, tidak terikat ruang dan waktu. Sebagai makhluk sosial manusia tidak bisa hidup sendiri di muka bumi ini. Manusia senantiasa membutuhkan interaksi dengan manusia lain baik secara berkelompok atau individu, baik dengan anggota kelompoknya maupun di luar kelompoknya. Islam mengajarkan umatnya untuk senantiasa menjaga hubungannya dengan manusia (hablum min as-naas), di samping menjaga hubungannya dengan AllahSWT (hablum min Allah). Allah SWT mengingatkan kita dalam Alqur'an surah Shaad/ 38 ayat 24 berbunyi:

Al Qalam: Jurnal Ilmiah Keagamaan dan Kemasyarakatan Vol. 16, No. 1 Januari - Juni 2022 
Fahrizal Akhirudin, Ujang Nurjaman : Momunikasi dan Human Relation Pendidikan Berbasis Agama, Filsafat, Psikologi dan Sosiologi

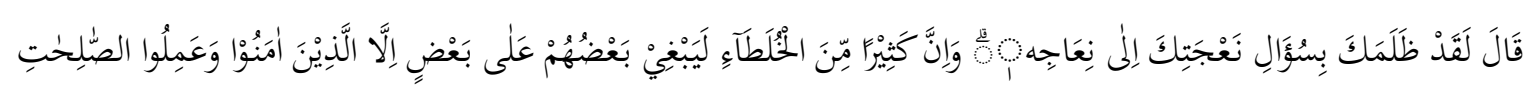

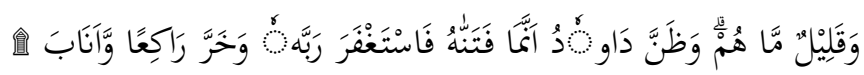

Dia (Dawud) berkata, "Sungguh, dia telah berbuat zalim kepadamu dengan meminta kambingmu itu untuk (ditambahkan) kepada kambingnya. Memang banyak di antara orang-orang yang bersekutu itu berbuat zalim kepada yang lain, kecuali orang-orang yang beriman dan mengerjakan kebajikan; dan hanya sedikitlah mereka yang begitu." Dan Dawud menduga bahwa Kami mengujinya; maka dia memohon ampunan kepada Tuhannya lalu menyungkur sujud dan bertobat.

Berdasarkan ayat tersebut terungkap bahwa ada kecenderungan manusia melakukakan kezaliman di antara sesamanya ketika mereka berhimpun dalam sebuah organisasi. Oleh karena itu Allah SWT mengingatkan bahwa hanya orangorang yang beriman dan beramal salehlah yang akan terhindar dari kezaliman dimaksud. Dengan keimanan yang teguh, seorang individu akan menyadari hakikat dirinya sebagai hamba Allah SWT yang memiliki hak dan kedudukan yang sama dengan individu lainnya di hadapan Allah SWT. Oleh karena itu, individu yang demikian ia akan membentengi dirinya dengan amal-amal saleh sehingga ia akan terbebas dari perbuatan zalim terhadap sesamanya. Hal tersebut juga berlaku dalam hubungan antara seorang pimpinan dan yang dipimpin. Menurut Nawawi, pimpinan memikul kewajiban dan tanggung jawab menciptakan dan membina hubungan manusiawi yang efektif, tidak saja dalam kepemimpinan keagamaan, akan tetapi dalam semua bidang kehidupan. Setiap umat Islam yang mendapatkan amanah menjadi pimpinan harus menyadari bahwa kepemimpinannya itu merupakan karunia, titipan, dan pinjaman Allah SWT. ${ }^{3}$

Dan yang perlu disadari oleh seorang pimpinan adalah bahwa tugas seorang pimpinan adalah untuk melindungi dan mengayomi hak-hak anggotanya, sehingga para anggota merasa aman, nyaman dan terpenuhi hakhaknya. Seorang pimpinan harus memiliki keteladan yang baik dalam hal pengetahuan, sikap maupun perilakunya, sehingga kredibilitas seorang pemimpin itu akan terbangun. Pimpinan yang baik adalah pimpinan yang menyadari tugas dan tanggung jawabnya sebagai pimpinan di dalam organisasi sehingga ia senantiasa menjaga hubungan baik dan kewibawaannya di mata anggotanya. Dalam membina human relation dengan anggota, maka perhatian utama pimpinan haruslah difokuskan pada keseimbangan antara hak dan kewajiban anggota. Pimpinan harus selalu berupaya untuk memotivasi anggota untuk selalu berprestasi dan meningkatkan kualitas kinerjanya. Bagi anggota yang berprestasi, pimpinan harus memberikan apresiasi sehingga anggota dimaksud merasa dihargai. Sebaliknya, jika anggota melakukan 1993), h. 13.

${ }^{3}$ Hadari Nawawi, Kepemimpinan Menurut Islam Yogyakarta (Yogyakarta: Gadjah Mada Universitas Press,

Al Qalam: Jurnal Ilmiah Keagamaan dan Kemasyarakatan Vol. 16, No. 1

Januari - Juni 2022 
Fahrizal Akhirudin, Ujang Nurjaman : Momunikasi dan Human Relation Pendidikan Berbasis Agama, Filsafat, Psikologi dan Sosiologi

kesalahan maka pimpinan seyogianya menegur dan mengingatkan dengan cara yang santun, sehingga anggota tidak merasa dipermalukan. Agar penerapan human relation dalam organisasi berlangsung dengan baik, maka seharusnya setiap pimpinan dan anggota organisasi memahami prinsip-prinsip human relation.

\section{Komunikasi Dan Human Relation Pendidikan Berbasis Filsafat}

Pemahaman atau komunikasi manusia merupakan masalah perspektif yang di pakai untuk memahaminya. Perspektif adalah sudut pandang dan cara pandang seseorang terhadap sesuatu. Cara seseorang memandang atau pendekatan yang digunakan dalam mengamati kenyataan akan menentukan pengetahuan yang diperoleh. Pada ilmu komunikasi ada beberapa metateori tentang realitas (ontologi), tentang bagaimana mencapainya (epistimologi), dan tentang nilai dari komunikasi (aksiologi). Berikut beberapa perspektif ontologi dan epistimologi: Realisme, bendabenda atau objek yang diamati sebagai apa adanya, telah berdiri secara benar, tanpa campur tangan ide dari si-pengamat. Nominalis, dunia sosial adalah wilayah luar pada persepsi individu, tersusun tidak lebih dari sekedar nama, konsep dan label yang digunakan untuk membuat struktur realitas. Konstruksionis, kita tidak pernah dapat mengerti realitas yang sesungguhnya secara ontologis.

a. Perspektif Positivisme

Apa itu komunikasi? Paradigma positivisme mendefiniskan komunikasi sebagi suatu proses sebab-akibat, yang mencerminkan pengirim pesan (komunikator/encoder) untuk mengubah pengetahuan (sikap atau perilaku) penerima pesan (komunikan/decoder) yang pasif. Komunikasi terjadi secara sengaja dilakukan oleh seseorang untuk menyampaikan rangsangan dalam membangkitkan respon orang lain. Model komunikasi linier atau komunikasi satu arah merupakan salah satu model yang paling banyak dikenal dan mudah dipahami.

b. Perspektif Post-Positivisme

Post-positivisme merupakan pemikiran yang menggugat asumsi kebenaran-kebenaran positivisme. Beberapa peneliti sosial beragumen bahwa kekurangan-kekurangan dari pemikiran positivisme pada dasarnya membutuhkan dasar filsafat ilmu yang berbeda. Namun, beberapa orang beranggapan bahwa postivisme sebenarnya tidak perlu ditolak secara total karena mereka lebih meletakkan penolakannya pada gagasan tentang keyakinan positivisme mengenai kebenaran absolut, landasan mutlak sebuah observasi dan asumsi tentang akumulasi pengetahuan yang tak berubah.

Perspektif Post-positivisme membawa pengaruh yang besar pada ilmu sosial termasuk ilmu komunikasi. Melalui kritik yang mendasar terhadap positivisme yang realis, bebas nilai dan memisahkan subjek dan objek penelitian.

Al Qalam: Jurnal Ilmiah Keagamaan dan Kemasyarakatan Vol. 16, No. 1 Januari - Juni 2022 
Fahrizal Akhirudin, Ujang Nurjaman : Momunikasi dan Human Relation Pendidikan Berbasis Agama, Filsafat, Psikologi dan Sosiologi

\section{c. Perspektif Interpretif}

Menurut Wilbur Schramm, manusia itu tidak mungkin tidak berkomunikasi. Kehidupan sosial seseorang dipenuhi dengan berbagai komunikasi. Teori ini menggambarkan proses munculnya pemahaman dari kehidupan sosial. Terori ini tidak mencoba menemukan struktur hukum dalam kehidupan sosial, melainkan berupaya membuka cara-cara orang memahami pengalaman mereka di tengah kehidupan sosial. Teori Interpretif ini diturunkan dalam teori komunikasi seperti teori interpretasi kultural, teori kultur organisasional dan teori interpretasi tekstual.

\section{d. Perspektif Konstruktivisme}

Konstruktivisme menolak pandangan positivisme yang memisahkan objek dan subjek komunikasi. Konstruktivisme menganggap subjek sebagi faktor sentral dalam kegiatan komunikasi. Konstruktivisme lebih berkaitan dengan program penelitian dalam komunikasi antarpersonal. ${ }^{4}$

Ilmu komunikasi dalam perspektif konstruktivisme tidak hanya mempertimbangkan konstruksi namun juga menyediakan cara-cara penelitian yang lebih khas. Namun wilayah komunikasi masih terus berkembang, karena itu perspektif ini mendapatkan kritik dan ilmu komunikasi berkembang lagi.

Dalam aspek epistemologi, ilmu komunikasi dikaji lebih mendalam. Para ilmuwan menanyakan bagaimana proses membangun pengetahuan atau teori-teori. Hal tersebut diwujudkan dengan pertanyaan-pertanyaan seperti apa, siapa, dimana, kapan, dan bagaimana ilmu komunikasi itu sendiri. Sedangkan dalam aspek aksiologi, ilmu komunikasi dipandang dari sisi nilai kajian dan etika tentang apa dan bagaimana pengaruh ilmu tersebut dalam masyarakat yang tujuannya bisa sebagai kritik sosial, transformasi, emansipasi, dan social empowerment.

Dalam pendekatan filsafat, gejala komunikasi dipelajari dengan menggunakan asumsi filosofis ontologi, epistemologi, dan aksiologi. ${ }^{5}$ Epistemologi adalah pertanyaan terhadap pengetahuan. Ontologi adalah pertanyaan tentang keberadaan. Axiologi adalah pertanyaan tentang nilai. Setiap teori, baik secara implisit maupun eksplisit, mengandung asumsi mengenai ilmu pengetahuan, keberadaan, dan nilai.

Sedangkan filsafat human relation dalam Sodikin, O., et.al. mengatakan Hubungan manusiawi adalah terjemahan dari human relation. Orang-orang juga ada yang menterjemahkan menjadi "hubungan manusia" atau juga diterjemahkan "hubungan antar manusia yang sebenarnya tidak terlalu salah karena yang berhubungansatu sama lain adalah manusia. Hanya saja, disini

\footnotetext{
${ }^{4}$ Elvinaro Ardianto and Bambang Q-Aness, Filsafat Ilmu Komunikasi: Suatu Pengantar (Bandung: PT Remaja Rosdakarya, 2009).

${ }^{5}$ Onong Uchjana Effendy, Human Relation and Public Relation (Bandung: Mandar Maju, 2009).
}

Al Qalam: Jurnal Ilmiah Keagamaan dan Kemasyarakatan Vol. 16, No. 1 Januari - Juni 2022 
Fahrizal Akhirudin, Ujang Nurjaman : Momunikasi dan Human Relation Pendidikan Berbasis Agama, Filsafat, Psikologi dan Sosiologi

sifat hubungan sesama manusianya tidak seperti orang berkomunikasi biasa,bukan hanya merupakan penyampaian suatu pesan oleh seseorang kepada orang lain, tetapi hubungan antara orang-orang yang berkomunikasi dimana mengandung unsur-unsur kejiwaan yang amat mendalam. Dikatakan bahwa hubungan manusiawi itu merupakan suatu komunikasi karena sifatnya yang orientasi pada perilaku (action oriented), hal ini mengandung kegiatan untuk mengubah sikap, pendapat, atau perilaku seseorang. Hubungan Antar "Manusia" adalah interaksi antara seseorang dengan orang lain baik dalam situasi kerja atau dalam organisasi kekaryaan. Ditinjau dari kepemimpinannya, yang bertanggung jawab dalam suatu kelompok merupakan interaksi orang-orang menuju situasi kerja yang memotivasi untuk bekerjasama secara produktif, sehingga dicapai kepuasan ekonomi, psikologis dan sosial. Ada dua pengertian hubungan manusiawi, yakni hubungan manusiawi dalam arti luas dan hubungan manusiawi dalam arti sempit. ${ }^{6}$

Manusia dan pendidikan merupakan hal yang betekerkaitan satu sama lain, di tinjau dari pendekatan filsafat pendidikan barat dikenal 3 aliran utama yang membahas hubungan antara manusia dan pendidikan, yakni aliran nativisme yang mana menyatakan bahwa manusia alam natur (potensi) bawaan manusia yang dominan dalam pendidikan, beda dengan empirisme yang dipelopori oleh John Locke ia berpendapat bahwa pengalaman dan lingkungan yang dominan, convergensi sebagai aliran penengah yang mana perpaduan antara faktor bawaan dan lingkungan yang menentukan perkembangan faktor bakat dan pendidikan.

\section{Komunikasi Dan Human Relation Pendidikan Berbasis Psikologis}

Menurut Abdurrahman, untuk melaksanakan human relation di lingkungan organisasi paling tidak ada 8 prinsip human relation yang harus dipahami, yaitu sebagai berikut: ${ }^{7}$
a. Importance of the individual (pentingnya individu)
b. Mutual acceptance (saling menerima)
c. Common interest (kepentinggan bersama)
d. Open communication (komunikasi terbuka)
e. Employees participation (partisipasi pegawai)
f. Local identity (identitas lokal)
g. Local need (kepentingan setempat)
h. High moral standarts (standar-standar moral yang tinggi)

Berdasarkan uraian tersebut dapat dipahami bahwa di dalam membina human relation,

\footnotetext{
${ }^{6}$ Oo Sodikin et al., "Komunikasi Dan Human Relation Pemimpin Pendidikan Berbasis Agama, Filsafat, Psikologi, Dan Sosiologi,” As-Salam: Jurnal Ilmiah Ilmu-Ilmu Keislaman 5, no. 1 (2021): h. 17.

${ }^{7}$ Abdurrachman Oemi, Dasar-Dasar Public Relations (Bandung: Citra Aditya Bakti, 2001), h. 17.
}

Al Qalam: Jurnal Ilmiah Keagamaan dan Kemasyarakatan Vol. 16, No. 1 Januari - Juni 2022 
Fahrizal Akhirudin, Ujang Nurjaman : Momunikasi dan Human Relation Pendidikan Berbasis Agama, Filsafat, Psikologi dan Sosiologi

maka eksistensi masing-masing individu di dalam organisasi diakui dan dihormati. Oleh karena itu harus dibangun sikap saling menerima di antara anggota organisasi. Selain itu, perbedaan kepentingan merupakan hal yang riskan di dalam organisasi. Oleh karena itu, seorang pimpinan organisasi harus bijak dalam menyatukan kepentingan-kepentingan yang berbeda tersebut, sehingga yang muncul adalah kepentingan bersama, tanpa membuat individu atau sekelompok orang merasa terzalimi.

Seorang pimpinan juga harus menjalin komunikasi yang akrab dan terbuka dengan jajarannya maupun dengan para anggotanya. Hal ini untuk menghindari sikap saling curiga dan juga untuk menjalin hubungan yang akrab di dalam organisasi. Dengan demikian, diharapkan para anggota akan senantiasa merasa sebagai bagian dari organisasi, yang mana hal ini akan mewujud dalam bentuk partisipasi dalam setiap upaya pencapaian tujuan organisasi. Untuk mencapai tujuan organisasi, harus dilakukan dengan cara-cara yang benar dan dengan menggunakan standar-standar moral yang tinggi. Pelanggaran sekecil apapun harus dihindari.

Komunikasi secara umum merupakan suatu proses penyampaian-penerimaan pesan antar dua orang atau lebih. Pesan yang disampaikan dapat berupa komunikasi lisan, komunukasi tulisan, komunikasi verbal, komunikasi non-verbal. Komunikasi tulisan suatu proses penyampaian pesan komunikasi dengan menggunakan kata-kata dalam bentuk tulisan yang memilki makna tertentu. Jadi dapat dikatakan bahwa komunikasi tulisan adalah kegiatan komunikasi yang menggunakan sarana tulisan yang dapat menggambarkan atau mewakili komunikasi lisan termasuk kedalamnya adalah menulis dan membaca.

Komunikasi efektif dalam pembelajaran merupakan proses transformasi pesan berupa ilmu pengetahuan dan teknologi dari pendidik kepada peserta didik, dimana peserta didik mampu memahami maksud pesan sesuai dengan tujuan yang telah ditentukan, sehingga menambah wawasan ilmu pengetahuan dan teknologi serta menimbulkan perubahan tingkah laku menjadi lebih baik. Pengajar adalah pihak yang paling bertanggungjawab terhadap berlangsungnya komunikasi yang efektif dalam pembelajaran.

Dengan menguasai dan mengembangkan beberapa strategi serta teknik berkomunikasi secara otomatis akan meningkatkan kemampuan untuk berhubungan dengan berbagai macam orang. Seorang pendidik bisa menciptakan dan mengembangkan komunikasi yang efektif melalui materi pembelajaran yang bisa diterima dan mudah dipahami oleh peserta didik.

Dalam komunikasi pendidikan, seorang pendidik harus mempunyai komunikasi pribadi yang baik karena ini akan berpengaruh untuk menciptakan hubungan yang harmonis antara pendidik dan peserta didiknya. Seorang pendidik juga harus mempunyai peranan yang penting

Al Qalam: Jurnal Ilmiah Keagamaan dan Kemasyarakatan Vol. 16, No. 1 Januari - Juni 2022 
Fahrizal Akhirudin, Ujang Nurjaman : Momunikasi dan Human Relation Pendidikan Berbasis Agama, Filsafat, Psikologi dan Sosiologi

untuk bisa mengendalikan kondisi kelas yang sehat karena merupakan tolak ukur keberhasilan.

\section{Komunikasi Dan Human Relation Pendidikan Berbasis Sosiologi}

Pada hakekatnya dalam suatu organisasi baik organisasi pemerintah maupun swasta, aktivitas human relations memegang peranan yang sangat penting karena semakin hari semakin dirasakan manfaatnya dalam membinan hubungan antara manusia di dalam suatu organisasi, menghilangkan benturan-benturan psikologis dan konflik-konflik antara kepentingan pribadi dan kepentingan organisasi yang terjadi di antara atasan dengan bawahan, bawahan dengan bawahan, meskipun tidak menyeluruh.

Berikut ini penulis mengemukakan beberapa pendapat para ahli untuk memperoleh pengertian human relations, yaitu sebagai berikut : Effendy human relation dalam arti luas adalah komunikasi persuasif yang dilakukan oleh seseorang kepada orang lain secara tatap muka dalam segala situasi dan dalam semua bidang kehidupan, sehingga menimbulkan kebahagiaan dan kepuasan hati pada kedua belah pihak. ${ }^{8}$

Dan secara sempit Effendy mengemukakan bahwa Human Relations adalah komunikasi persuasif yang dilakukan oleh seseorang kepada orang lain secara tatap muka dalam situasi kerja (work situation) dan dalam organisasi kekaryaan (work organization) dengan tujuan untuk menggugah kegairahan dan kegiatan bekerja dengan semangat kerja sama yang produktif dengan perasaan bahagia dan puas hati. Apabila individu-individu di dalam suatu organisasi telah dapat menyatukan dirinya dengan setiap pekerjaan dan merasa perlu dengan pekerjaan tersebut karena ia merasakan manfaat dan kenyamanan dalam lingkungan kerjanya. Kondisi seperti itu yang sangat dibutuhkan untuk mempertahankan dan memelihara keutuhan suatu organisasi dalam mencapai tujuannya. ${ }^{9}$

Menurut Siagian:

Human relation adalah keseluruhan rangkaian hubungan, baik yang bersifat formal maupun informal, antara atasan dengan bawahan, atasan dengan atasan, serta bawahan dengan bawahan yang lain yang harus dibina dan dipelihara sedemikian rupa sehingga tercipta suatu team work dan suasana kerja yang serasi dan harmonis dalam rangka pencapaian tujuan. ${ }^{10}$

Manusia di dalam suatu organisasi baik hubungan formal maupun informal dalam menciptakan dan mewujudkan suatu kerja sama yang intim dan harmonis guna mencapai tujuan yang telah ditetapkan dengan di landasi saling pengertian dan saling menghargai. Dari pengertian human relation itu dapat ditarik kesimpulan bahwa human relation adalah suatu komunikasi

\footnotetext{
${ }^{8}$ Uchjana Effendy, Human Relation and Public Relation, h. 48.

${ }^{9}$ Ibid., h. 50.

${ }^{10}$ Sondang P Siagian, Manajemen Sumber Daya Manusia (Jakarta: Bumi Aksara, 2008), h. 6.
}

Al Qalam: Jurnal Ilmiah Keagamaan dan Kemasyarakatan Vol. 16, No. 1 Januari - Juni 2022 
Fahrizal Akhirudin, Ujang Nurjaman : Momunikasi dan Human Relation Pendidikan Berbasis Agama, Filsafat, Psikologi dan Sosiologi

persuasif, bukan hanya sekedar relasi atau hubungan saja. Jadi human relation bukan suatu keadaan yang pasif, melainkan suatu aktivitas, suatu kegiatan. Dan dipandang dari sudut pandang seorang pemimpin yang bertanggung jawab untuk memimpin sebuah kelompok, human relation adalah pengintegrasian orang-orang kedalam suatu situasi kerja yang menggiatkan mereka untuk bekerja bersama-sama serta dengan rasa puas, baik kepuasan ekonomis, psikologis, maupun kepuasan sosial.

\section{Ide Kreatif Dalam Membangun Komunikasi Dan Human Relation Pendidikan}

Tujuan Komunikasi, diantaranya:

a. Untuk mempelajari secara lebih baik dunia luar, seperti berbagai objek, peristiwa dan orang lain. Meskipun informasi tentang dunia luar itukita kenal umumnya melalui mass media, tetapi hal itu pada akhirnya seringkali didiskusikan, dipelajari, diinternalisasi melalui komunikasi dalam pembelajaran. Nilai-nilai, system kepercayaan, dan sikap-sikap nampaknya lebih banyak dipengaruhi oleh pertemuan interpersonal dari pada dipengaruhi media bahkan sekolah.

b. Untuk memelihara hubungan dan mengembangkan kedekatan atau keakraban. Melalui komunikasi kita berkeinginan untuk menjalin rasa cinta dan kasih sayang. Disamping cara demikian mengurangi rasa kesepian atau rasa depresi, komunikasi bertujuan membagi dan meningkatkan rasa bahagia yang pada akhirnya mengembangkan perasaan positif tentang diri kita sendir Kita diajari tidak boleh iri, dengki, dendam, saling fitnah dan saling bunuh; kita semua akan mati dan dikuburkan orang lain.

c. Melalui komunikasi, seorang pendidik mencoba mencapai tujuan pembelajaran dengan cara berinteraksi dengan peserta didik; membagi informasi atau gagasan, melakukan tukar pengalaman, mendorong dan saling membentuk sikap- sikapdan kebiasaan-kebiasaan baru yang efektif berdasarkan persepsi yang diperoleh selama pembelajaran.

Ide kreatif dalam membangun komunikasi dan human relations, penulis mengacu kepada sepuluh dimensi dalam prinsip-prinsip human relation sebagai berikut :

a. Upaya untuk mengatasi hambatan kurangnya anggaran yang dimiliki pimpinan mengusahakan anggaran dari anggaran yang lain sehingga pegawai dapat mengikuti pelatihan-pelatihan.

b. Upaya untuk mengatasi hambatan mengenai adanya beberapa pegawai yang tidak setuju dengan keputusan pimpinan, yakni dengan pimpinan menjelaskan apa yang menjadi kesalahpahaman antar keduanya, dan memberikan penjelasan kepada pegawai yang tidak sesuai dengan keputusan pimpinan dengan cara memusyawarahkannya sehingga di

Al Qalam: Jurnal Ilmiah Keagamaan dan Kemasyarakatan Vol. 16, No. 1

Januari - Juni 2022 
Fahrizal Akhirudin, Ujang Nurjaman : Momunikasi dan Human Relation Pendidikan Berbasis Agama, Filsafat, Psikologi dan Sosiologi

dapatnya solusi dari hambatan tersebut.

c. Upaya untuk mengatasi hamabatan mengenai sikap pimpinan yang tidak mau menerima saran dari pegawai, yakni pimpinan seyogyanya menelaah terlebih dahulu apa yang menjadi saran dari pegawai dan apabila saran tersebut benar untuk kemajuan organisasi seyogyanya pimpinan menerimanya dengan lapang dada dan mengenai sikap pimpinan yang keras dalam menyampaikan saran, yakni pimpinan seyogyanya bernada lembut dan tidak bersifat memarahi ketika menegur pegawai yang salah.

d. Upaya untuk menyelesaikan hambatan mengenai sulitnya menyesuaikan pekerjaan pegawai yang sesuai dengan kemampuan pegawai, yakni pimpinan seyogyanya memahami kemampuan dari masing-masing pegawai supaya tidak terjadinya kesalahan dalam memberikan pekerjaan kepada pegawai dan mengenai ketidak sesuaian anggaran dengan kenyataan, yakni pimpinan seyogyanya mengupayakan anggaran dari dana lain.

e. Upaya untuk mengatasi hamabatan kurangnya kepercayaan pimpinan terhadap kemampuan kerja pegawai yaitu seyogyanya pegawai memberikan semua kemampuannya untuk melaksanakan ugasnya agar hasilnya maksimal dan kepercayaan pimpinan pun dapat bertambah dan mengenai cara menegur pimpinan yang keras, yakni seyogyanya pimpinan bersikap lembut ketika menegur pegawai yang salah supaya pegawai tidak merasa tersinggung terhadap saran dari pimpinan.

Komunikasi pendidikan sangat diperlukan demi keberlangsungan pendidikan. Proses belajar-mengajar merupakan komunikasi antara seorang guru dengan muridnya. Di sini, diperlukan penyampaian pesan yang efektif dengan tujuan pesan yang berisi topik-topik tertentu dapat diterima dengan baik oleh peserta didik. Oleh karena itu, seorang guru hendaknya menyadari bahwa dalam kegiatan belajar mengajar itu sesungguhnya ia sedang berkomunikasi. Guru harus pandai dan memilih kalimat yang mudah dimengerti oleh muridnya. dengan demikian pesan yang ingin disampaikan dapat diterima dengan baik oleh muridnyadan kkomunikasi pendidikan dapat berjalan dengan baik. komunikasi pada hakekatnya adalah suatu proses sosial yaitu sesuatu yang berlangsung atau berjalan antara manusia. sebagai proses sosial dalam komunikasi terjadi interaksi individu dengan lingkungannya. inilah yang akhirnya menyebabkan terjadinya proses perubahan prilaku dari tidak tahu menjadi tahu dari tidak paham menjadi paham.

Didalam UU No. 20 Tahun 2003 tentang Sistem Pendidikan Nasional Bab II Pasal 3 disampaikan tujuan pendidikan nasional. Yang mana tujuan tersebut adalah untuk mengembangkan potensi peserta didik agar menjadi manusia yang beriman dan bertakwa kepada Tuhan Yang Maha Esa, beraklak mulia, sehat, berilmu, cakap, kreatif, mandiri, dan menjadi warga yang demokratis

Al Qalam: Jurnal Ilmiah Keagamaan dan Kemasyarakatan Vol. 16, No. 1 Januari - Juni 2022 
Fahrizal Akhirudin, Ujang Nurjaman : Momunikasi dan Human Relation Pendidikan Berbasis Agama, Filsafat, Psikologi dan Sosiologi

serta bertanggung jawab.

Ide kreatif dalam membangun komunikasi dan human relations dapat digambarkan pada bagai di bawah ini

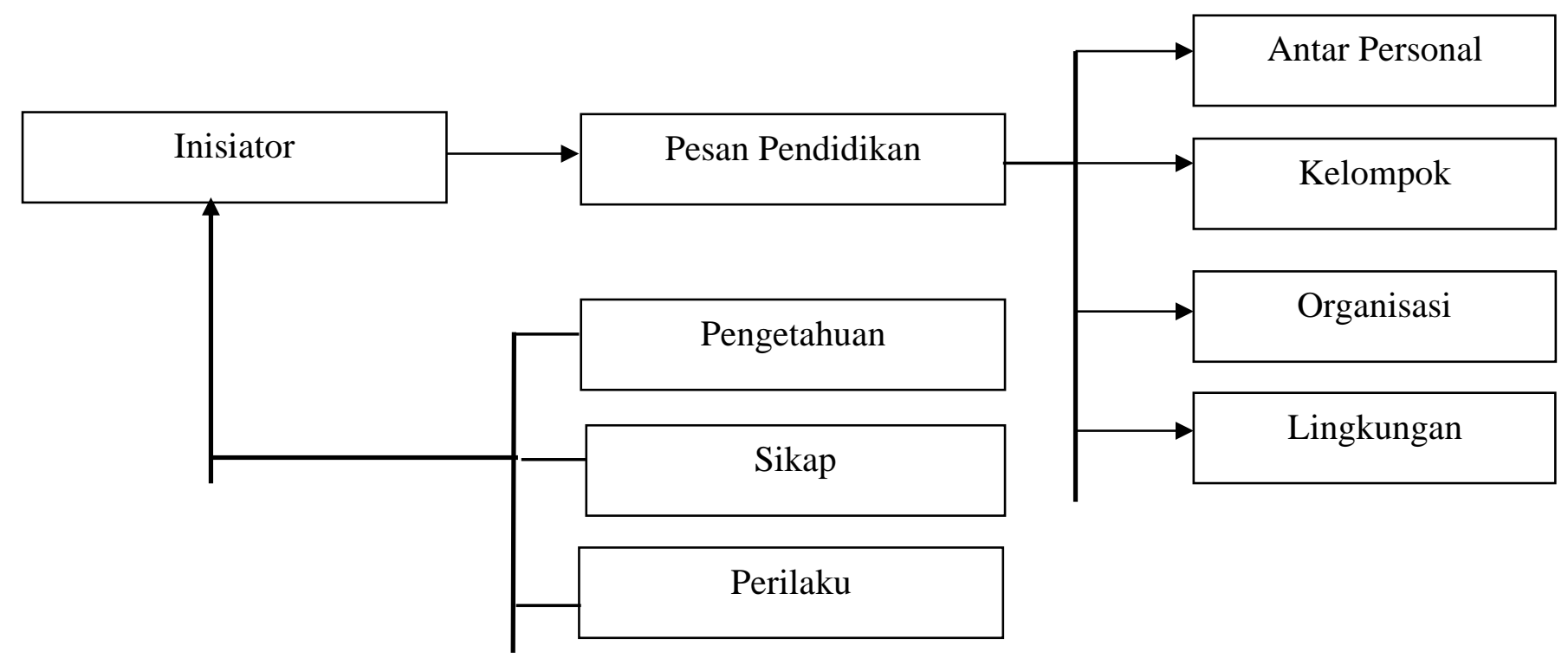

Gambar:

Proses Komunikasi Pendidikan

Selanjutnya digambarkan human relation pendidikan yang digambarkan berdasrkan hasil pembahasan di atas:

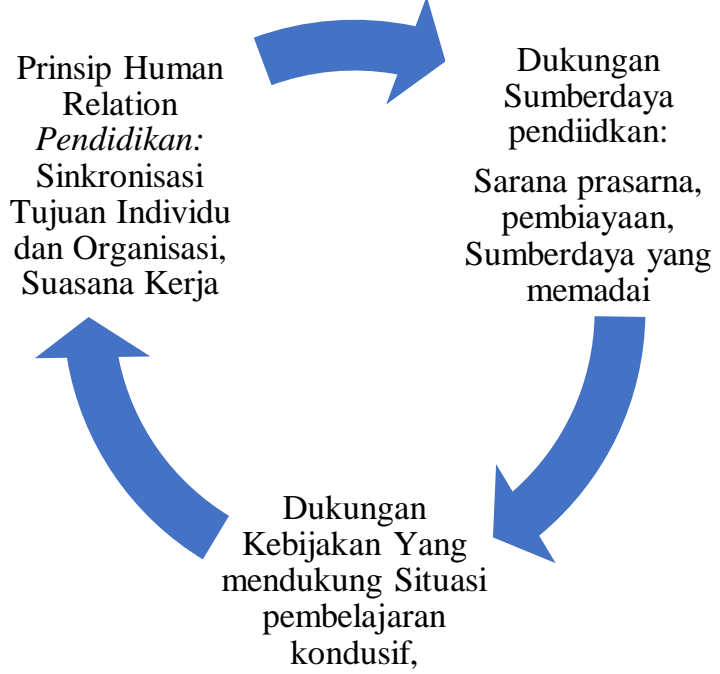

\section{KESIMPULAN DAN SARAN}

Al Qalam: Jurnal Ilmiah Keagamaan dan Kemasyarakatan Vol. 16, No. 1

Januari - Juni 2022 
Fahrizal Akhirudin, Ujang Nurjaman : Momunikasi dan Human Relation Pendidikan Berbasis Agama, Filsafat, Psikologi dan Sosiologi

Urgensi human relation dalam komunikasi organisasi. Berdasarkan paparan-paparan dalam makalah ini dapat disimpulkan bahwa human relation merupakan salah satu teknik komunikasi yang harus diterapkan di dalam komunikasi organisasi guna mendukung pencapaian tujuan organisasi. Terwujudnya kepuasan bersama di antara partisipan komunikasi adalah ciri khas dari teknik human relation. Pimpinan organisasi bertanggungjawab sebagai pelopor untuk menerapkan human relation dalam komunikasi organisasi. Sebab, sesuai dengan kedudukannya, pimpinan organisasi harus menjadi pengayom sekaligus suri tauladan bagi para anggotanya. Perilaku pimpinan akan diwarisi oleh anggotanya. Ibarat kunci dan gembok, kunci human relation dalam komunikasi organisasi ada pada pimpinan organisasi. Adapun gemboknya adalah anggota organisasi.

Manusia sejak dini pastinya sudah memiliki pengalaman serta pendidikan baik yang didapat secara otodidak maupun dari orang lain, Manusia merupakan mahkluk tanpa daya, yang mana sejak dilahirkan ia membutuhkan bantuan dari lingkungannya, membutuhka intervensi (pengaruh dilingkungannya.

Komunikasi dalam pendidikan merupakan unsur yang sangat penting kedudukannya. Bahkan sangat besar peranannya dalam menentukan keberhasilan pendidikan yang bersangkutan. Orang sering berkata bahwa tinggi-rendahnya suatu capaian mutu pendidikan dipengaruhi pula oleh faktor komunikasi ini, khususnya komunikasi pendidikan.

\section{DAFTAR PUSTAKA}

Ardianto, Elvinaro, and Bambang Q-Aness. Filsafat Ilmu Komunikasi: Suatu Pengantar. Bandung: PT Remaja Rosdakarya, 2009.

Burhan, Bungin. Sosiologi Komunikasi: Teori, Paradigma, Dan Diskursus Teknologi Komunikasi Di Masyarakat. Jakarta: Kencana Prenada Media Group, 2006.

Nawawi, Hadari. Kepemimpinan Menurut Islam Yogyakarta. Yogyakarta: Gadjah Mada Universitas Press, 1993.

Oemi, Abdurrachman. Dasar-Dasar Public Relations. Bandung: Citra Aditya Bakti, 2001.

Rizki, Juni Wati Sri. "Urgensi Human Relation Bagi Organisasi." Studi Multidisipliner: Jurnal Kajian Keislaman 2, no. 1 (2015): 130-144.

Siagian, Sondang P. Manajemen Sumber Daya Manusia. Jakarta: Bumi Aksara, 2008.

Sodikin, Oo, Deddy Hendriady, Sofyan Sauri, and Faiz Karim Fathullah. "Komunikasi Dan Human Relation Pemimpin Pendidikan Berbasis Agama, Filsafat, Psikologi, Dan Sosiologi." AsSalam: Jurnal Ilmiah Ilmu-Ilmu Keislaman 5, no. 1 (2021): 14-31.

Uchjana Effendy, Onong. Human Relation and Public Relation. Bandung: Mandar Maju, 2009.

Al Qalam: Jurnal Ilmiah Keagamaan dan Kemasyarakatan Vol. 16, No. 1

Januari - Juni 2022 